INTIQAD: JURNAL AGAMA DAN PENDIDIKAN ISLAM

ISSN 1979-9950 (print) || ISSN 2598-0033 (online), http://jurnal.umsu.ac.id/index.php/intiqad

DOI: 10.30596/intiqad.v12i2.5557

Vol. 12, No. 2 (December 2020)

\title{
Tanggung Jawab Pendidikan Perspektif Pendidikan Islam
}

\author{
Fatkhur Rohman $^{1^{*}}$ \\ Universitas Islam Negeri Sumatera Utara Medan*1 \\ ${ }^{*}$ email: fatkhurrohman@ uinsu.ac.id
}

\begin{abstract}
Responsibility is human awareness behavior or actionsof intentional or unintentional, and has the meaning of awarenessmanifesting the obligation to carry it out. Humans feel responsible because they realized of the good or bad consequences of their actions, and also realize that the other requires their dedication or sacrifice. In the Islamic educationperspective, the responsibility for Islamic education is carried out by parents, teachers, schools, the environment, government and other with an interest in education world. Some aspects of the Islamic educationresponsibility that great concern are education of tawhid (faith), morals, physicality, intellect, heart (psychic), social and sexual education. This paper is an attempt to understand the responsibility of perspective educators in Islamic education, by using a literature review approach.
\end{abstract}

Artikel Info

Received:

Keywords: Responsibility, Educators, Islamic Education.

\section{Abstrak}

Tanggung jawab merupakan kesadaran manusia akan tingkah laku atau perbuatan yang disengaja maupun yang tidak disengaja, serta memiliki makna perwujudan kesadaran akan kewajiban melaksanakannya. Manusia merasa bertanggung jawab karena ia menyadari akibat baik atau buruk perbuatannya itu, dan menyadari pula bahwa pihak lain memerlukan pengabdian atau pengorbanannya. Dalam perspektif pendidikan Islam, tanggung jawab pendidikan Islam dilaksanakan oleh kedua orang tua, guru, sekolah, lingkungan sekitar, pemerintah dan pihak lain yang berkepentingan dalam dunia pendidikan. Beberapa aspek tanggung jawab pendidikan Islam yang sangat diperhatikan adalah pendidikan tauhid (iman), akhlak, fisik, akal, kalbu (psikis), sosial dan pendidikan seksual. Tulisan ini merupakan upaya untuk memahami tanggung jawab 
pendidikan perspektif pendidikan Islam, dengan menggunakan pendekatan kajian kepustakaan.

\section{Kata Kunci: Tanggung Jawab, Pendidik Pendidikan Islam.}

\section{A. Pendahuluan}

Pendidikan Islam merupakan suatu aktivitas yang berkelanjutan dalam proses merubah akhlak tiap-tiap individu dengan cara pengajaran, untuk menuju kebaikan pribadi, masyarakat dan lingkungan sekitarnya sesuai kebutuhan masyarakat (al-Syaibani, 1979). Ada tiga pendekatan yang dapat dilakukan untuk menelaah tugas-tugas pendidikan Islam, yaitu: (1) pendidikan bertujuan untuk mengembangkan potensi; (2) pendidikan bagian dari mewariskan budaya; dan (3) pendidikan bertujuan sebagai interaksi antara mengembangkan potensi dan mewariskan budaya. Ketiga hal tersebut saling berkaitan dan merupakan satu kesatuan yang utuh (Langgulung, 1988).

Pada dasarnya, tanggung jawab pendidikan itu dimulai dari lingkungan keluarga yang berawal dari anak dalam kandungan, kemudian lahir, bertahap mengalami pertumbuhan dan perkembangan, sampai anak menjadi orang dewasa yang menyadari segala kewajibannya, kemudian masyarakat, sekolah, pemerintah, dan lembaga lain yang memiliki kepentingan dalam pendidikan.

Islam sangat perduli dan solutif tentang mendidik anak dalam keluarga sesuai dengan usianya. Sebagaimana yang telah dipraktikkan oleh Rasulullah Saw. Pola asuh pendidikan anak dapat dimulai dengan cara membimbing dan belajar sambil bermain pada usia anak 07 tahun; menanamkan sikap sopan santun dan disiplin ketika anak berusia 7-14 tahun; dan ajaklah mereka bertukar pikiran pada usia anak 14-21 tahun, dan kemudian beri kebebasan kepada mereka untuk mandiri (Padjrin, 2016).

Manusia diciptaan Allah Swt. juga dibekali dengan naluri untuk menjadi seorang pendidik kodrati, yakni untuk menumbuh kembangkan, melindungi, memelihara dan mendidik anak-anaknya. Naluri itu sejalan dengan naluri untuk mempertahankan keturunan, agar tidak punah dari muka bumi (Nawani, 1993). Dengan demikian sepanjang masa sejak diturunkannya 
manusia pertama Adam dan Hawa, sampai akhir zaman kelak, manusia akan tetap memiliki keturunan, yang memerlukan perlindungan, pemeliharaan dan pendidikan sebelum mampu melindungi dirinya sendiri dan orang lain sebagai orang dewasa.

Dari uraian di atas, dapat dipahami bahwa manusia memiliki rasa tanggung jawab untuk mendidik, meneruskan dan memelihara serta menyelamatkan keturunannya, karena manusia diciptakan Allah diberikan kelebihan sebagaimana yang tidak dimiliki oleh makhluk lainnya. Allah swt. berfirman pada Q.S. al-Isra' ayat 70:

Artinya: Dan sesungguhnya telah Kami muliakan anak-anak Adam, Kami angkut mereka di daratan dan di lautan, Kami beri mereka rezeki dari yang baik-baik dan Kami lebihkan mereka dengan kelebihan yang sempurna atas kebanyakan makhluk yang telah Kami ciptakan dengan sempurna.

Quraish Shihab, dalam tafsirnya menjelaskan: Sungguh Allah telah memuliakan anak cucu Adam dengan bentuk tubuh yang sempurna, kemampuan berbicara dan kebebasan memilih. Mereka Allah berikan kemuliaan dan kekuatan, jika mereka mematuhi Tuhan-nya. Mereka Allah angkut di daratan, melalui hewan, dan Allah angkut pula mereka di lautan, melalui kapal-kapal. Mereka juga Allah berikan rezeki dengan berbagai kenikmatan. Sesungguhnya Allah benarbenar telah melebihkan mereka berupa akal pikiran atas kebanyakan makhluk lain yang Allah ciptakan (Shihab, 2002).

berdasarkan uraian di atas, penulis akan mendeskripsikan tentang tanggung jawab pendidikan dalam perspektif pendidikan Islam, yang dibatasi dan terfokus pada tanggung jawab pendidikan iman (tauhid), akhlak, fisik, akal, kalbu (psikis), sosial dan pendidikan seksual.

\section{B. Tanggung Jawab Pendidikan Islam}

Dalam Kamus Bahasa Indonesia (Nasional, 2019), tanggung jawab adalah keadaan wajib menanggung segala sesuatunya (kalau terjadi apa-apa boleh dituntut, dipersalahkan, diperkarakan, dan sebagainya). Dengan kata lain, tanggung jawab adalah suatu konsekuensi dari perbuatan. sebab sesuatu perbuatan harus dapat dipertanggungjawabkan pada siapapun. 
ISSN 1979-9950 (print) || ISSN 2598-0033 (online), http://jurnal.umsu.ac.id/index.php/intiqad DOI: 10.30596/intiqad.v12i2.5557

Vol. 12, No. 2 (December 2020)

Begitu juga dalam tanggungjawab pendidikan Islam

Kemudian muncul pertanyaan, siapakah yang bertanggung jawab dalam pendidikan Islam tersebut? Tentunya jawaban ini tidaklah semata-mata hanya dibebankan kepada guru di sekolah saja, melainkan kedua orang sebagai pendidik pertama dan utama, kemudian guru di sekolah, masyarakat sekitar, pemerintah dan lembaga-lembaga lainnya yang berkepentigan di dunia pendidikan. Dalam realitanya memang masih ada cara pandang yang salah dari sebagian orang tua terhadap pendidikan anak. Seolah, apabila anak sudah dimasukkan ke sekolah maka tanggung jawab pendidikan sepenuhnya dilakukan oleh guru atau pihak sekolah. Di sinilah perlu sebuah kerjasama orang tua siswa dengan guru dan pihak sekolah, agar pendidikan dapat terlaksana dengan baik.

\section{Tanggung Jawab Pendidikan Iman}

(Tauhid)

Secara umum, pendidikan, pengalaman dan latihan-latihan yang dilaluinya dapat menentukan ketaatan seseorang dalam beragama (Darajat, 2005). Lebih lanjut lagi dikatakan ketika masa anak-anak tidak pernah dididik agama, maka baginya ketika dewasa nanti ia merasa agama tidak penting dalam kehidupannya. Berbeda bila seseorang pada waktu anak-anak dididik agama dan memiliki pengalaman beragama, baik di rumah, lingkungan sosial, sekolah dan masyarakat. sehingga dengan sendirinya anak tersebut ketika menjadi orang dewasa akan cenderung hidup sesuai dalam ajaran agama, terbiasa melaksanakan perintah agama dan meninggalkan larangannya serta dapat merasakan betapa nikmatnya hidup dengan mengamalkan agama. Hal tersebut sebagaimana disebutkan alQur'an pada surat Luqman ayat 13 dikisahkan.

Artinya: Dan (ingatlah) ketika Luqman berkata kepada anaknya, di waktu ia memberi pelajaran kepadanya: "Hai anakku, janganlah kamu mempersekutukan Allah, sesungguhnya mempersekutukan (Allah) adalah benarbenar kezaliman yang besar.

Tujuan pendidikan agama Islam dalam konsep tauhid menurut pemikiran Abdul Karim Amrullah adalah untuk menyiapkan manusia menjadi beriman kepada Allah, bertakwa, dan memiliki ilmu pengetahuan, memiliki tanggung jawab serta, berakhlak mulia (Saputro, 2016). 
Pendidikan iman (tauhid) yang dimaksud adalah mendidik anak sebagaimana yang terkandung dalam rukun Islam, rukun iman, dan dasar syari'ah, mulai anak mampu memahami dan mampu membedakan baik dan buruk (Ulwan, 1993). Dasar-dasar iman adalah menyakini dan mengamalkan isi kandungan dari rukun iman tersebut. Sedangkan orang Islam yang dikatakan sempurna keislamannya bila melaksakan rukun Islam dengan baik, serta melaksanakan dan mengamalkan dasardasar syariat sesuai jalan Ilahi dan ajaran Islam, seperti aqidah, ibadah, akhlak, peraturan, dan perundang-undangan yang berlaku.

Tugas dan tanggung jawab pendidik adalah menumbuh kembangkan pemahaman dasar-dasar iman dan ajaran Islam pada anak. Dengan demikian anak akan terbiasa dengan aturan-aturan dan ajaran Islam. Beberapa cara Pendidikan iman (tauhid) kepada anak sesuai dengan tuntunan Nabi Muhammad saw, yakni: memulai dengan menanamkan kalimat La Ilaha Illallah pada anak yg baru lahir; mengenalkan tentang hukum yang halal dan haram, memerintahkan anak ketika usia tujuh tahun untuk beribadah (shalat), dan mengajarkan anak untuk cinta kepada Rasul, keluarga dan keturunannya, serta membimbing dan membiasakan membaca al-Qur'an (Ulwan, 2003)

Di samping itu, Syeikh Ahmad Farid menguraikan bahwa pendidikan iman adalah upaya meningkatkan kualitas iman generasi muda Islam dan memupuk pohon iman yang ada di dalam hati mereka, hal tersebut dapat dilakukan dengan beberapa cara:

a. Memperdalam pengetahuan mereka tentang Allah swt, asma-asma-Nya, sifat-sifat-Nya, rububiyah-Nya dan ilahiyah-Nya;

b. Merenungkan isi kandungan alQur'an dan Hadis Nabi;

c. Mengenal Nabi saw, dengan cara mempelajari sejarah Nabi, mukjizatmukjizat dan bukti-bukti kenabian, serta mengetahui kemuliaan nasab, akhlak dan petunjuknya merupakan sarana yang paling efektif untuk menambah iman;

1) Mempelajari kebaikan-kebaikan Islam;

2) Memikirkan makhluk Allah swt, dengan cara menggunakan akal dan fikiran kita untuk mengenal dan berfikir akan kebesaran dan keagungan-Nya yang telah 
ISSN 1979-9950 (print) || ISSN 2598-0033 (online), http://jurnal.umsu.ac.id/index.php/intiqad

DOI: 10.30596/intiqad.v12i2.5557

Vol. 12, No. 2 (December 2020)

menciptakan alam dan isinya yang dapat dimanfaatkan oleh manusia itu sendiri.

3) Memperbanyak ibadah-ibadah sunnah setelah mengamalkan ibadah-ibadah yang wajib;

4) Menjalani hidup di dalam atmosfir iman dan menghirup udara iman, serta menjauhi atmosfir maksiat, syahwat dan subhat;

5) Banyak berzikir kepada Allah swt; dan

6) Terlibat aktif dalam kegiatan dakwah (Farid, 2011).

Sedangkan menurut Djamarah, ada lima pendekatan yang ditawarkan dalam menumbuhkan nilai Ilahiyah kepada anak dalam keluarga, yaitu pengalaman, pembiasaan, emosional, rasional dan fungsional (Djamarah, 2017).

Muhammad Usman Najati, juga mengatakan bahwa keimanan pada akidah tauhid merupakan langkah awal menciptakan perubahan besar dalam kepribadian (Najati, 2005). Keimanan tersebut dapat melahirkan kekuatan spiritual yang merubah pemahaman manusia tentang dirinya, orang lain, kehidupan dan kosmos secara keseluruhan. Berkat keimanan tersebut, qalbu manusia dipenuhi cinta kepada Allah swt., Rasul-Nya, orang-rang di sekitarnya dan manusia secara umum, sehingga terpancar ketenangan dan ketentraman dalam hidupnya.

\section{Tanggung Jawab Pendidikan Akhlak (Moral/Budi Pekerti)}

Sebagaimana dikatakan oleh AlAbrasyi, bahwa pendidikan Islam bertujuan untuk membentuk pribadi murid agar memiliki akhlakul karimah. Pendidikan akhlak merupakan ruh dari tujuan pendidikan Islam. Hal ini bukan berarti bahwa pendidikan Islam mengesampingkan aspek-aspek pendidikan lainnya seperti halnya pendidikan fisik (jasmani), akal atau ilmu praktis lainnya (al-Abrasyi, 2003).

Maksud dari pendidikan akhlak adalah pendidikan tentang moral, tabiat dan keutamaan perilaku yang harus senantiasa diajarkan dan ditanamkan pada anak, sehingga anak bisa membedakan akhlak yang baik dan akhlak tercela, sampai menjadi orang dewasa yang mandiri (Ulwan, 2003). Maka, tidak diragukan lagi bahwa seseorang yang berakhlak mulia akan menjadikan manusia lebih religius dan menghormati sesama dan ciptaan Allah yang lainnya. 
Untuk membentuk pribadi anak memiliki karakter yang baik maka sebagai orang tua wajib mempersiapkan semenjak sebelum perkawinan, saat masih dalam kandungan dan setelah lahir, kemudian sebagai pendidik harus memiliki sifat-sifat dasar antara lain: ikhlas, takwa, berilmu, penyabar dan tanggungjawab. Kemudian, proses pendidikan dapat terlaksana sesuai dengan harapan, maka pendidik harus memberikan beberapa metode yang sesuai dan kondisional untuk anak, melalui keteladanan, kebiasaan, wasiat, nasehat, perhatian, pengawasan dan metode reward and punishmant (Subur, 2017).

Akhlak dalam ajaran Islam menempati posisi penting dan juga menjadi misi dari kerasulan Muhammad saw. Sebagaimana dijelaskan dalam hadis Nabi saw (Baihaqi, 2003):

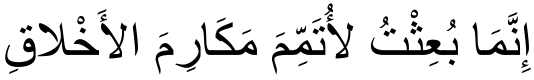

"Sesungguhnya aku diutus hanya untuk menyempurnakan keshalihan akhlak." (HR. Al-Bayhaqi dalam al-Sunan alKubrâ' (No. 20782).

Akhlak bukanlah aturan untuk mengatur perilaku manusia saja, tetapi mengatur hubungan manusia secara vertikal (habl min al-Allah), horizontal (habl min al-Nas) dan diagonal (habl min al-alam). Akhlak merupakan intisari dari semua kebaikan dan keutamaannya dapat memberi nilai tinggi pada seorang muslim di sisi Allah dan makhluk Allah yang lain. Keimanan dan keislaman seseorang dinilai kurang sempurna, apabila tanpa dibingkai dengan akhlakul karimah (Lubis, 2011).

Menurut Ibnu Maskawaih dalam bukunya Ahmad Farid, akhlak adalah suatu keadaan kejiwaan seseorang yang berbuat untuk melakukan sesuatu tanpa pertimbangan dan pemikiran. keadaan ini terbagi menjadi dua macam: (1) Kondisi yang berasal dari watak dasar seseorang secara alami, dan (2) Kondisi diperoleh melalui latihan dan kebiasaan (Farid, 2011).

Dalam Islam pendidikan akhlak dipahami sebagai sebuah latihan psikis dan fisik. Latihan ini dapat menciptakan seseorang memiliki kebiasaan untuk menjalankan perintah Allah dengan rasa tanggung jawab yang tinggi (Abdullah, 2007). Latihan-latihan ini bisa bersifat formal (seperti di sekolah), maupun bersifat non-formal (lingkungan sekitar). Dapat dikatakan bahwa, pendidikan akhlak dapat dijadikan sebagai sarana 
ISSN 1979-9950 (print) || ISSN 2598-0033 (online), http://jurnal.umsu.ac.id/index.php/intiqad

DOI: 10.30596/intiqad.v12i2.5557

Vol. 12, No. 2 (December 2020)

untuk menciptakan pribadi seseorang yang berakhlakul karimah. Pribadi yang berakhlakul karimah akan mampu menjalankan perintah Allah dan Rasulnya, menjaga hubungan baik pada manusia, dan ciptaan Allah lainnya.

Pembinaan akhlak merupakan bagian dari tujuan pendidikan Islam. Sebagaimana tujuan pendidikan Islam adalah menciptakan manusia agar beriman, dan bertakwa kepada Allah, Memiliki ilmu pengetahuan, ketrampilan dan berperilaku sesuai dengan nilai keislaman (Syafri, 2014). Untuk mewujudkan salah satu tujuan pendidikan Islam, maka nilai-nilai akhlakul karimah harus ditanamkan sejak anak usia dini melalui pembudayaan dan pembiasaan yang dimulai dari lingkungan keluarga (Al Munawar, 2005). Sehingga akan terbiasa dan dipraktikkan dalam kehidupan bermasyarakat. Di sinilah perlunya peran pendidik, pemuka agama, dan lembaga adat yang dapat mengambil peran terdepan di masyarakat dalam pembinaan akhlak anak tersebut, sehingga pada akhirnya mampu mengaplikasikannya dalam kehidupan beragama, berbangsa dan bernegara.
Pendidikan akhlak memiliki relevansi yang signifikan terhadap pendidikan agama. Dapat dipahami bahwa pendidikan akhlak dalam Islam merupakan suatu bagian yang tidak bisa terpisahkan dari pendidikan agama. Sebab, sesuatu itu disebut baik barometernya adalah baik dalam pandangan agama, begitu juga sebaliknya.

Akhlak adalah alat kontrol sosial dan psikis bagi individu dan masyarakat. Inilah yang membedakan manusia dengan makhluk lainnya. Keberhasilan pendidikan Islam akan terlihat pada akhlak peserta didiknya (Al Munawar, 2005). Rasulullah saw. adalah uswatun hasanah yang wajib menjadi contoh dan diteladani setiap muslim, karena beliau memiliki akhlak yang sangat agung dan mulia (lihat Q.S. Al-Qalam: 4).

\section{Tanggung Jawab Pendidikan Fisik}

Sejak zaman dahulu, mulai dari manusia purba sampai pada kehidupan zaman modern sekarang ini, kesehatan, kekuatan, dan kebugaran tubuh selalu jadi perhatian utama. Islam sendiri sangat perhatian terhadap pendidikan fisik pada anak, karena fisik yang sehat akan menentukan keberhasilan dalam 
ISSN 1979-9950 (print) || ISSN 2598-0033 (online), http://jurnal.umsu.ac.id/index.php/intiqad

DOI: 10.30596/intiqad.v12i2.5557

Vol. 12, No. 2 (December 2020)

tahapan-tahapan pendidikan lainnya (Daradjat, 1995).

Kemudian muncul pertanyaan, siapa sajakah yang memiliki tanggung jawab dalam pendidikan fisik anak? Apabila dirunut dari tanggung jawab tersebut, maka tak lain jawabannya kedua orang tua (ayah dan ibu), kerena keduanya adalah pendidik pertama dan utama. Kemudian tanggung jawab selanjutnya seperti guru dan pendidik lainnya. Dengan tujuan, supaya anak nantinya tumbuh menjadi dewasa, memiliki tubuh yang sehat, kuat, memiliki gairah dan semangat.

Berkaitan dengan pendidikan fisik, Islam mengajarkan beberapa metode praktis agar anak tumbuh dengan baik sesuai harapan, diantaranya:

a. Memberi nafkah pada anak dan keluarga adalah bagian dari kewajiban.

b. Memakan makanan dan minuman yang sehat, serta tidur yang teratur.

c. Menghindari dari penyakit yang menular.

d. Memberi obat bila sedang sakit.

e. Menerapkan dasar: "untuk tidak memberikan sesuatu yang tidak memiliki manfaat". f. Membiasakan anak untuk berolah raga

g. Membiasakan anak untuk zuhud dan tidak tenggelam dalam kenikmatan

h. Membiasakan anak untuk bekerja keras dan bersungguh-sungguh,agar tidak menyimpang dan menjadi pengangguran (Ulwan, 1993).

\section{Tanggung Jawab Pendidikan Akal (Rasio)}

Maksud dari pendidikan akal atau disebut juga dengan pendidikan intelektual adalah pendidikan untuk membentuk pola fikir anak yang memiliki manfaat, baik ilmu pengetahuan, teknologi dan kemajuan zaman. Intelektual disebut juga kecakapan (ability) yang mampu memahami, mengenal, menilai, menganalisis, dan memecahkan berbagai masalah dengan akal (Sukmadinata, 2005). Nashih Ulwan, mengatakan bahwa tanggung jawab pendidik terhadap pendidikan akal (intelektual) berpusat pada tiga permasalahan yaitu: (1) Mengajar sebagai sebuah kewajiban;

(2) Penyadaran berfikir; dan

Pemeliharaan intelektual (Ulwan, 1993).

John W. Santrock sendiri mengatakan bahwa banyak yang 
INTIQAD: JURNAL AGAMA DAN PENDIDIKAN ISLAM

ISSN 1979-9950 (print) || ISSN 2598-0033 (online), http://jurnal.umsu.ac.id/index.php/intiqad

DOI: 10.30596/intiqad.v12i2.5557

Vol. 12, No. 2 (December 2020)

mengklaim tentang bagaimana pendidikan anak harus disesuaikan dengan kemampuan otak. Pendidikan harus memperhatikan tingkat kemampuan anak berdasarkan pertumbuhan dan perkembangan otak (Santrock, 2015). Sedangkan menurut Harun Nasution, akal yang dimaksud disini bukanlah otak yang bagian dari anggota tubuh, tetapi daya nalar yang terdapat pada jiwa manusia. Dengan memperhatikan alam sekitar, akal berfungsi sebagai alat untuk memperoleh ilmu pengetahuan (Nasution, 1986).

Ada beberapa cara orang tua dalam melakukan pendidikan akal (intelektual) pada anak, yakni:

a. Menyiapkan kenyamanan dan rangsangan belajar dalam rumah tangga. Seperti belajar sambil bermain, menggunakan media gambar-gambar, dan sebagainya.

b. Membiasakan anak untuk berfikir logis dalam menyelesaikan setiap masalah yang ia hadapi dan memberi contoh yang baik.

c. Membiasakan anak mengaitkan sebab-akibat, hal-hal yang harus dilakukan sebagai pendahuluan sampai pada kesimpulan. d. Membiasakan anak berfikir obyektif, bijaksana dalam mengambil sebuah keputusan, dan berani jujur sesuai kenyataan yang terjadi (Langgulung, 1986).

Setelah anak masuk kelembaga pendidikan (sekolah), maka tanggung jawab keluarga dalam pendidikan akal (intelektual) bertambah banyak seperti: menyiapkan suasana belajar yang nyaman dan sesuai, mengulang pelajaran dan mengerjakan tugas, bekerja sama dengan sekolah untuk menyelesaikan masalah-masalah belajar, dan membiasakan mereka untuk mengulangi pelajaran di rumah.

\section{Tanggung Jawab Pendidikan} Kalbu (Psikis)

Pendidikan kalbu (psikis) dimaksudkan di sini adalah mendidik anak supaya memiliki sikap keberanian, jujur, mengutamakan kebenaran, suka berbuat baik terhadap orang lain, dan mampu menahan diri ketika dalam kondisi tidak stabil (marah) (Ulwan, 1993). Tujuan dari pendidikan kalbu ini diantaranya membentuk, menyempurnakan dan menjaga keseimbangan kepribadian anak. Sehingga anak nantinya akan dapat 
INTIQAD: JURNAL AGAMA DAN PENDIDIKAN ISLAM

ISSN 1979-9950 (print) || ISSN 2598-0033 (online), http://jurnal.umsu.ac.id/index.php/intiqad

DOI: 10.30596/intiqad.v12i2.5557

Vol. 12, No. 2 (December 2020)

melaksanakan kewajiban-kewajiban yang dibebankan pada dirinya dengan baik sesuai ajaran agama Islam.

Ketika lahir, anak telah menjadi amanah bagi kedua orang tua dan pendidik lainnya, menanamkan padanya dasar-dasar kesehatan psikis (kalbu) agar anak nantinya menjadi manusia yang berakal, berfikir sehat, bijaksana dalam bertindak, penuh perhitungan dan memiliki kemauan tinggi dalam berbuat kebaikan.

Pendidikan dalam perspektif psikologi agama memiliki tanggung jawab terhadap perkembangan anak didik. Secara terminologi pendidikan adalah usaha sadar untuk melakukan perubahan sikap dan perilaku menuju kedewasaan. Indikator dari kedewasaaan adalah tanggung jawab dan amanah. Membangun manusia menjadi dewasa bukanlah hal yang mudah, seperti membangun sebuah bangunan, sebab manuia adalah makhluk yang hidup yang dapat merespon, mempengaruhi dan dipengaruhi. Dengan demikian, tanggung jawab pendidikan sangat vital terhadap perkembangan kehidupan manusia untuk mencapai tujuan dunia dan akhirat (Anwar, 2014).
Di dalam pendidikan kalbu ini, ada dua aspek yang diperhatikan, yakni: pertama, kalbu yang bersifat jasmani, dan kedua, kalbu yang bersifat ruhani (halus /lathif), rabbani, dan ruhani yang berhubungan dengan kalbu jasmani, dan inilah yang merupakan inti dari manusia (Al-Ghazali, tt).

Komponen fisik tercermin di dalam kalbu jasmani. Sedangkan komponen psikis tercermin di dalam ruhani. Kalbu jasmani berfungsi sebagai pusat peredaran dan pengaturan darah, dan bila fungsi ini berhenti, maka manusia akan mati. Meskipun jantung bersifat fisik, akan tetapi ia berhubungan erat dengan kondisi psikologinya. Apabila kalbu ini berfungsi secara normal, maka kehidupan manusia menjadi lebih baik dan sesuai dengan fitrah aslinya, sebab kalbu ini memiliki natur Ilahiyat atau Rabaniyat. Natur Ilahiyat merupakan natur supra kesadaran manusia, yang dipancarkan dari Tuhan. Dengan natur ini manusia tidak hanya sekedar mengenal lingkungan fisik dan sosialnya, melainkan juga mampu mengenal lingkungan spiritual, ketuhanan dan keagamaan. Oleh karena natur inilah, maka kalbu disebut juga fitrah Ilahiyat 
atau fitrah Rabbaniyat-nuraniyat (Mujib, 2000).

Sejalan dengan hal tersebut di atas, Baharuddin juga menjelaskan bahwa struktur psikis manusia merupakan komponen yang utuh dalam melambangkan sistem organisasi manusia, yang masing-masing dimensi psikis membentuk suatu komposisi, yakni: al-nafs sebagai elemen dasar psikis manusia; al-ruh,sebagai dimensi spiritual psikis manusia; dan fitrah sebagai dimensi identitas esensial psikis manusia. Dimensi fitrah inilah yang menjadikan identitas kemanusiaan kepada dimensi-dimensi psikis manusia secara keseluruhan (Baharuddin, 2007).

\section{Tanggung Jawab Pendidikan Sosial}

Pendidikan sosial dimaksudkan adalah membiasakan anak dari kecil untuk melaksanakan adab sosial dengan baik yang didasarkan pada psikis yang baik dan bersumber pada ajaran Islam, agar tertanam rasa keimanan, sehingga dalam bermasyarakat nantinya dapat menampilkan perilaku dan akhlak yang baik, seimbang akal dan bijaksana dalam bertindak (Ulwan, 1993).
Perlakuan dan bimbingan orang tua sangat mempengaruhi terhadap perkembangan sosial anak. Seperti mengenalkan norma-norma dalam kehidupan bermasyarakat dan memberi contoh pada anak bagaimana normanorma tersebut dapat diterapkan di masyarakat dalam kehidupan sehari-hari (Yusuf, 2016).

Tidak diragukan lagi bahwa tanggung jawab pendidikan sosial adalah bagian terpenting yang harus menjadi perhatian orang tua dan pendidik lainnya. Pendidikan ini merupakan manifestasi perilaku dan karakter mendidik anak untuk menjalankan haknya, tata krama, kritik sosial, keseimbangan intelektual, politik dan pergaulan yang baik dengan orang lain.

Ada beberapa upaya-upaya untuk mewujudkan pendidikan sosial atau masyarakat melalui pendekatan pendidikan Islam, yakni (Nata, 2014):

a. Memberikan wawasan kemasyarakatan yang berdasarkan al-Qur'an dan Hadis. Ayat-ayat dan hadis-hadis tentang hablum minannas (hubungan baik dengan manusia) harus disandingkan dengan ayat-ayat dan hadis-hadis 
INTIQAD: JURNAL AGAMA DAN PENDIDIKAN ISLAM

ISSN 1979-9950 (print) || ISSN 2598-0033 (online), http://jurnal.umsu.ac.id/index.php/intiqad

DOI: 10.30596/intiqad.v12i2.5557

Vol. 12, No. 2 (December 2020)

tentang hablum minallah (hubungan

baik dengan Allah swt).

b. Memberikan wawasan, contoh dan praktik mengamalkan ayat al-Qur'an dan hadis yang erat kaitannya dengan kehidupan sosial, seperti tolong menolong, berbaik sangka, toleransi, saling menasehati, mengucapkan salam, memberi hormat, memelihara lingkungan, mengatasi kemiskinan, kebodohan dan lain sebagainya.

c. Menunjukkan contoh-contoh tentang kegiatan sosial yang berdasarkan nilai-nilai ajaran Islam, seperti contoh penanggulangan banjir, memelihara kebersihan, dan sebagainya.

Lebih lanjut dijelaskan oleh Ulwan tentang beberapa metode dalam pendidikan sosial ini, diantaranya:

1) Menanamkan dasar-dasar psikis yang mulia;

Hal ini dapat dilakukan dengan menanamkan ketaqwaan kepada anak (peserta didik), persaudaraan antar sesama, mengajarkan kasih sayang, mengutamakan orang lain, memberi maaf kepada orang lain, dan mengajarkan keberanian untuk senantiasa berbuat benar.
2) Memelihara hak-hak orang lain

Memelihara dan menjaga hak-hak masyarakat, saling berkaitan erat dengan dasar-dasar psikis yang bermakna. Bahkan dengan suatu ungkapan yang jelas, bahwa dasardasar psikis merupakan suatu makna, sedangkan pemeliharaan hak-hak masyarakat merupakan manifestasinya. Salah satu contoh yang harus kita disampaikan kepada anak (peserta didik) sebagai upaya pendidikan sosial yang baik adalah: hak terhadap kedua orang tua, saudara-saudaranya, teman sejawat, tetangga, guru, dan hak orang lain yang lebih dewasa.

3) Melaksanakan tata kesopanan sosial Sejak masa kecil, anak dibiasakan untuk melakukan dasar-dasar tata kesopanan sosial sebagaimana yang diajarkan dalam Islam. Hal ini dapat diajarkan kepada anak (peserta didik) seperti dengan membiasakan adab memberi salam, adab meminta izin, adab di dalam majlis, adab berbicara, adab bergurau, adab makan dan minum, adab mengucapkan selamat, adab menjenguk orang sakit, adab berta'ziyah serta adab bersin dan menguap. 
4) Pengawasan dan kritik sosial

Membiasakan anak melaksanakan kewajiban amar ma'ruf \& nahi munkar, yang merupakan salah satu dasar Islam yang fundamental di dalam memeliharan pendapat umum, memerangi kerusakan dan penyimpangan serta memelihara nilai, keteladanan dan akhlak umat Islam (Ulwan, 1993).

\section{Tanggung Jawab Pendidikan Seksual}

Menurut al-Qur'an, manusia diciptakan Allah SWT. berpasangan lelaki-perempuan dan kepada mereka dianugerahi cinta dan kasih sayang, dan sudah menjadi fitrahnya bahwa manusia ingin mencintai dan dicintai. Tercapainya kebutuhan cinta itu, jika ditunaikan secara benar maka hal itu akan membuat manusia merasa tentram, tenang dan bahagia, begitu juga dengan sebaliknya. Cinta itu sendiri diungkap dalam bahasa Arab dengan tiga kelompok karakteristik, yaitu: (1) apresiatif (ta'dzim), orang yang dicintai itu menempati kedudukan seperti harimau atau pedang (yang ditakuti dan dikagumi), (2) penuh perhatian (ihtimaman), seperti bencana (yang harus diwaspadai), dan (3) Cinta (mahabbah), seperti minuman keras (yang membuat ketagihan). Ketiga karakteristik ini terkumpul dalam ungkapan mahabbah, orangnya disebut habib, habibah dan mahbub. Atas dasar inilah, maka tanggung jawab pendidikan seks harus dimulai dari pendidikan keluarga (Mubarok, 2016).

Tanggung jawab pendidikan seksual merupakan upaya untuk memberikan pemahaman, pengajaran dan penyadaran kepada anak tentang masalah seksual, naluri dan perkawinan. Pendidikan ini dilakukan berdasarkan tingkatan usia anak yaitu:

a. Usia 7-10 tahun (masa tamyiz atau masa pra-pubertas). Pada usia ini, etika meminta izin dan memandang sesuatu diajarkan pada anak.

b. Usia 10-14 tahun (masa murahaqah atau masa pubertas/peralihan). pada usia ini berbagai macam yang dapat merangsang seksual harus dijauhkan dari anak.

c. Usia 14-16 tahun (masa bulugh atau masa adolesen/remaja). Pada usia ini anak diberi pelajaran etika (adab) dalam hubungan seksual, apabila anak sudah siap untuk menikah. 
ISSN 1979-9950 (print) || ISSN 2598-0033 (online), http://jurnal.umsu.ac.id/index.php/intiqad

DOI: 10.30596/intiqad.v12i2.5557

Vol. 12, No. 2 (December 2020)

d. Usia setelah masa adolesen (remaja atau pemuda). Pada usia ini anak diajarkan menjaga kehormatan diri (isti'faf), apabila ia memang belum mampu untuk melaksanakan pernikahan (Ulwan, 1993).

Kemudian muncul pertanyaan, bolehkah pendidikan masalah seksual diberikan kepada anak, sedangkan ia masih tamyiz? Maka secara terperinci sesuai dengan fase di atas, pendidik diharapkan mampu mengetahui cara-cara mendidik dan mengarahkan anak dalam hal pendidikan seksual dengan memperhatikan (Ulwan, 1993):

1) Adab-adab meminta izin, sebagaimana dalam al-Qur'an surat an-Nuur ayat 58-59, menjelaskan bahwa ada tiga hal adab yang diajarkan pada anak di bawah usia remaja, sehingga anak harus meminta izin pada keluarganya: Pertama, sebelum shalat fajar. Karena, waktu itu kebiasaan orangorang masih tidur (istirahat) di tempat tidur mereka. Kedua, pada waktu zuhur. Karena, waktu itu kebiasaan orang-orang

menanggalkan pakaiannya bersama keluarga. Ketiga, setelah shalat isya. Karena, waktu itu kebiasaan orang beristirahat dan tidur malam. Ketiga izin ini memiliki nilai paedagogis tentang dasar-dasar adab yang baik bersama keluarga.

2) Adab memandang

Masalah penting yang harus diperhatikan di sini adalah mengajari anak dari usia tamyiz untuk terbiasa memandang yang baik-baik. Dengan maksud agar anak mampu memilah mana yang dibolehkan dan dilarang dalam memandang. Sehingga nantinya anak telah dibekali adab yang baik ketika mendekati usia remaja dan menuju dewasa.

\section{Simpulan}

Dari paparan di atas, dapat ditarik kesimpulan bahwa tangung jawab pendidikan Islam terhadap anak tidaklah semata dibebankan hanya kepada guru sebagai pendidik di sekolah, melainkan kedua orang tua sebagai pendidik pertama dan utama dalam mendidik anak-anaknya, mulai dari dalam kandungan, ketika lahir, tumbuh dan berkembang dari bayi, masa kanakkanak, masa remaja dan menuju pada kedewasaan seseorang yang ditandai dengan kemandirian hidup, dan mampu mengaplikasikan pendidikan yang 
ISSN 1979-9950 (print) || ISSN 2598-0033 (online), http://jurnal.umsu.ac.id/index.php/intiqad

DOI: 10.30596/intiqad.v12i2.5557

Vol. 12, No. 2 (December 2020)

diperolehnya dalam kehidupan masa kini dan masa yang akan datang.

Di samping itu, dalam melaksanakan tugas dan tanggung jawab pendidikan Islam terhadap anak diperlukannya kerjasama antara kedua orang tua dengan guru di sekolah, lingkungan sekitar dan masyarakat, pemerintah serta lembaga-lembaga lain yang memiliki kepentingan di dunia pendidikan. Dengan demikian, tujuan dalam pendidikan Islam baik pendidikan Iman (tauhid), pendidikan akhlak (budi pekerti), pendidikan akal (rasio), pendidikan fisik dan psikis, serta pendidikan sosial akan tercapai dengan baik, sehingga anak (peserta didik) memiliki bekal untuk menuju kehidupan yang lebih baik dengan berlandaskan pada iman, berakhlakul karimah, menguasai ilmu pengetahuan, memiliki fisik dan psikis yang sehat dan kuat, memiliki jiwa sosial yang tinggi, serta memiliki pengetahuan seksual yang baik, sehingga ia mampu mengendalikan dirinya dan siap menjadi seorang yang akan mengemban amanah dalam kehidupan kedepannya.

\section{Daftar Pustaka}

Al Munawar, S. A. H. (2005). Aktualisasi Nilai-Nilai Qur'ani dalam Sistem Pendidikan Islam. Ciputat: Ciputat Press.

Al-Abrasyi, M. A. (2003). PrinsipPrinsip Dasar Pendidikan Islam. terj. Abdullah Zakiy Al-Kaaf, Bandung: Pustaka Setia.

Al-Baihaqi, A. B. A. (2003) Al Sunan Al Qubra, Juz 10. Beirut: Darul Qutub al-'Ilmiah.

Al-Ghazali, A. H. M. (t.t). Ihya' Ulum al-Din: Fitrah dan Kepribadian, Beirut: Dar al-Fikr, juz III.

Al-Syaibani, O. M. T. (1979). Falsafah al-Tarbiyah al-Islamiyah, (terj.) Hasan Langgulung. Jakarta: Bulan Bintang.

Anwar, S. S. (2014). Tanggung Jawab Pendidikan Dalam Perspektif Psikologi Agama. Psympathic: Jurnal Ilmiah Psikologi, 1(1), 1121.

Baharuddin. (2007). Paradigma Psikologi Islam: Studi tentang Elemen Psikologi dari Al-Qur'an. Yogyakarta: Pustaka Pelajar.

Daradjat, Z. (1995). Pendidikan Islam dalam Keluarga dan Sekolah. Jakarta: Ruhama. 
INTIQAD: JURNAL AGAMA DAN PENDIDIKAN ISLAM

ISSN 1979-9950 (print) || ISSN 2598-0033 (online), http://jurnal.umsu.ac.id/index.php/intiqad DOI: 10.30596/intiqad.v12i2.5557

Vol. 12, No. 2 (December 2020)

Daradjat, Z. (2005). Ilmu Jiwa Agama,

Jakarta: Bulan Bintang, cet. ke-17.

Djamarah, S. B. (2017). Pola Asuh

Orang Tua dan Komunikasi dalam

Keluarga: Upaya Membangun

Citra Membentuk Pribadi Anak, Jakarta: Rineka Cipta.

Farid, S. A. (2011). At-Tarbiyah Ala Manhaji Ahlissunnah Wal Jama'ah. terj. Najib Junaidi: Pendidikan Berbasis Metode Ahlus Sunnah wal Jamaah, Surabaya: eLBA.

Langgulung. H. (1988) Pendidikan Islam

Menghadapi Abad ke-21. Jakarta:

Pustaka Al Husna.

Langgulung. H. (1989), Manusia dan Pendidikan: Suatu Analisa Psikologi dan Pendidikan. Jakarta: Al Husna.

Lubis, S. A. (2011). Konseling Islami dan Kesehatan Mental, Bandung: Citapustaka Media Perintis.

Mubarok, A. (2016). Psikologi Keluarga, Malang: Madani.

Mujib, A. (2000). Fitrah dan Kepribadian Islam: Sebuah Pendekatan Psikologis, Jakarta: Darul Falah.

Najati, M. U. (2005). Psikologi dalam Al-Qur'an: Terapi Qurani dalam
Penyembuhan

Gangguan

Kejiwaan, terj. M. Zaka Alfarisi, Bandung: Pustaka Setia.

Nasional, D. P. (2019). Kamus besar bahasa Indonesia.

Nasution, H. (1986). Akal dan Wahyu dalam Islam, Jakarta: UI Press.

Nata, A. (2014). Sosiologi Pendidikan Islam, Jakarta: Raja GRafido Persada.

Nawawi, H. (1993). Pendidikan dalam Islam, Surabaya: Al-Ikhlas

Padjrin, P. (2016). Pola Asuh Anak dalam Perspektif Pendidikan Islam. Jurnal Intelektualita: Keislaman, Sosial dan Sains, 5(1), $1-14$.

Santrock, J. W. (2015). Psikologi Pendidikan. edisi kedua. Jakarta: Prenada Media Group.

Saputro, I. (2016). Konsep Tauhid Menurut Abdul Karim Amrullah dan Implikasinya terhadap Tujuan Pendidikan Islam. At-Ta'dib, 11(2), 259-284.

Shihab, M. Q. (2002). Tafsir al-Misbah, Vol. VII. Jakarta: Lentera Hati.

Subur, S. (2017). Membentuk Karakter Anak Perspektif Islam: Kajian Dari Aspek Tanggung Jawab 
INTIQAD: JURNAL AGAMA DAN PENDIDIKAN ISLAM

ISSN 1979-9950 (print) || ISSN 2598-0033 (online), http://jurnal.umsu.ac.id/index.php/intiqad DOI: 10.30596/intiqad.v12i2.5557

Vol. 12, No. 2 (December 2020)

Pendidik. Jurnal Tarbiyatuna, 8(2), 146-165.

Sukmadinata, N. S. (2005). Landasan Psikologi Proses Pendidikan. Bandung: Remaja Rosdakarya.

Syafri, U. A. (2014). Pendidikan Karakter Berbasis Al-Qur'an, Jakarta: Raja Grafindo Persada.

Ulwan, A. N. (1993). Tarbiyatu al-Aulad Fi al-Islam. Terj. Saifullah
Kamalie \& Hery Noer Ali: Pedoman Pendidikan Anak dalam Islam. Semarang: Asy-Syifa’ . Yatimin, A. (2007). Studi Akhlak dalam Perspektif Al-Qur'an. Jakarta: Amzah.

Yusuf, S. (2016). Psikologi Perkembangan Anak \& Remaja. Bandung: Remaja Rosdakarya. 